компетентність - це система властивостей особистості, що забезпечують ефективне, раціональне і творче використання знань і вмінь для самостійного розв 'язання завдань у міжособистісних стосунках в умовах професійних ситуацій та інтересах освітнього закладу.

\title{
Література
}

1. Овчарук О. В. Компетентності як ключ до оновлення змісту освіти / О. В. Овчарук // Стратегія реформування освіти в Україні: Рекомендації 3 освітньої політики. - К. : К.І.С., 2003. - 296 с. 2. Зимняя И. А. Ключевые компетенции как результативно-целевая основа компетентностного подхода в образовании/ И. А. Зимняя. - М. : Просвещение, 2004. - 180 с. 3. Равен Дж. Компетентность в современном обществе / Дж. Равен. - М. : Когнито-Центр, 2002.- 396 с. 4. Петровская Л. А. Компетентность в общении: социально-психологический тренинг. / Л. А. Петровская. - М. : МГУ, 1989. - 216 с. 5. Кузьмина Н. В. Профессионализм личности преподавателя и мастера производственного обучения / Н. В. Кузьмина. - М. : Просвещение, 1990. - 119 с.

УДК 372.011.31:373.2

Інна Кондратець

\section{РОЛЬ ІННОВАЦЙНИХ ТЕХНОЛОГІЙ У ПРОЦЕСІ ФОРМУВАННЯ РЕФЛЕКСИВНОЇ КУЛЬТУРИ ПЕДАГОГІВ ДОШКІЛЬНИХ НАВЧАЛЬНИХ ЗАКЛАДІВ}

Кондратець I. В. Роль інноваційних технологій у процесі формування рефлексивної культури педагогів дошкільних навчальних закладів.

Стаття присвячена проблемі формування рефлексивної культури у педагогів дошкільних навчальних закладів в умовах упровадження інноваційних технологій. Здійснено аналіз сучасного стану проблеми, конкретизовано зміст та методи формування рефлексії, запропоновано методи і прийоми, що сприяють розвиткові рефлексивних умінь і навичок.

Ключові слова: рефлексія, рефлексивна культура, рефлексивне середовище, рефлексивні уміння і навички, інноваційні технології.

Кондратец И. В. Роль инновационнных технологий в процессе формирования рефлексивной культуры педагогов дошкольных образовательных заведений.

Статья посвящена проблеме формирования рефлексивной культуры у педагогов дошкольных образовательных учреждений в условиях внедрения инновационных технологий. Осуществлён анализ современного состояния проблемы, конкретизирована суть и методы формирования рефлексии у педагогов, предложены методы и приёмы, которые способствуют эффективному развитию рефлексивных умений и навыков.

Ключевые слова: рефлексия, рефлексивная культура, рефлексивная среда, рефлексивные умения и навыки, инновационные технологии.

Kondratec I. V. The function of innovvative technologies in the process of forming of reflection culture of teachers of preschool educational establishments.

The article is devoted the problem of forming of reflection culture for the teachers of preschool educational establishments in the conditions of introduction of innovative technologies. The analysis of the modern state of problem is carried out, essence and methods 
of forming of reflection is specified for teachers, methods and receptions which are instrumental in effective development of reflection abilities and skills.

Key words: reflection, reflection culture, reflection environment, reflection abilities and skills, innovative technologies.

Освітянська практика змінюється постійно, інакше вона не буде відповідати тим вимогам, які суспільство висуває до освітніх закладів. Ці зміни здійснюються за рахунок створення, і послідовного впровадження різного виду нововведень. Сучасний спосіб розвитку й удосконалення системи освіти визначається як інноваційний процес, що розуміється як комплексна діяльність із створення, засвоєння, використання i розповсюдження нововведень. Інновації, як правило, виникають на межі кількох проблем і розв'язують принципово нові задачі, ведуть до безперервного оновлення освітнього процесу.

Новим орієнтиром у діяльності методичних служб має стати не стільки процес інформування педагогів про наукові досягнення та досвід інноваційної практики, скільки організація інноваційної діяльності самих педагогів шляхом самоосвіти, самоорганізації й саморозвитку засобами опанування новими компетенціями. Надзвичайно важливим у цьому аспекті є навчання вихователів поетапному плануванню власної інноваційної діяльності на основі конкретизації завдань реалізації кожного етапу, визначення змісту й очікуваних результатів відповідно до загальної мети здійснюваної роботи. 3 огляду на зазначені проблеми актуальним стає питання формування рефлексивної культури в педагогів дошкільних навчальних закладів.

Дослідження рефлексії було започатковане у працях видатних філософів Р. Декарта, Д. Локка, І. Канта, Г. Гегеля, В. Лекторського, В. Лефевра; психологів Ж. Піаже, Дж. Дьюї, Б. Ананьєва, Л. Виготського, С. Рубінштейна і отримало своє продовження в дослідженнях сучасних науковців Н. Алексєєва, Є. Ісаєва, І. Ладенко,
А. Карпова
I. Семенова,
С. Степанова,
В. Слободчикова,
В. Сластьоніна, Г. Щедровицького. Вагомий внесок у наближення теоретичних положень про рефлексивну культуру до практики професійної діяльності педагога зроблено І. Бехом,
Г. Бізяєвою,
Б. Вульфовим,
Г. Єрмаковою,
В. Кременем,
Ю. Кулюткіним,

С. Максименком, А. Марковою.

Сучасні вітчизняні науковці Н. Гавриш, І. Дичківська, К. Крутій, Ю. Манилюк, Т. Піроженко, Т. Поніманська вказують на значну роль педагогічної рефлексії у формуванні особистісних та професійних якостей педагогів дошкільних навчальних закладів.

На сучасному етапі розвитку психолого-педагогічної галузі низка прикладних досліджень розкриває процеси здійснення рефлексії у різних видах діяльності. Натомість проблема розвитку рефлексивної культури педагога дошкільного навчального закладу донині займає маргинальну позицію, що істотно обмежує пошук шляхів професійного удосконалення педагога у його готовності до інноваційної діяльності. Причини, пов'язані з низьким рівнем рефлексивної культури у педагогів, на наш погляд, потрібно шукати ще на етапі підготовки майбутніх спеціалістів, а також у системі післядипломної освіти - у більшості консервативній і формалістичній у своїх підходах, методах та формах.

Meта статmі - визначення шляхів формування рефлексивної культури педагогів дошкільних навчальних закладів засобом використання інноваційних технологій, 3'ясування необхідних для цього педагогічних умов.

Підготовка та навчання в системі вищої освіти й післядипломної освіти висококваліфікованих спеціалістів на сучасному рівні передбачає не тільки організацію 
глибокого, системного і якісного засвоєння ними фундаментальних знань, формування відповідних практичних умінь і навичок, але й розвиток у них мотиваційно-емоційної сфери, здатностей до самореалізації і творчості. Соціальна потреба в педагогахпрофесіоналах помітно посилила інтерес науковців до вивчення структури й закономірностей розвитку рефлексивної культури.

Проблема рефлексії (reflexio (лат.) - «звернення назад») $\epsilon$ нині актуальною у психолого-педагогічній науці. У широкому розумінні рефлексія- це міркування, самовладання, осмислення, самоаналіз своєї діяльності в системі взаємозв'язків зі світом, у якому живе особистість.

Професійна рефлексія є невід'ємним складником роботи педагога і становить собою співвіднесення себе і можливостей свого «Я» 3 тим, чого вимагає педагогічна професія. Розвинута здатність до педагогічної рефлексії $є$ передумовою самовиховання педагога, творчого пошуку, розвитку індивідуального стилю педагогічної діяльності.

Т. Поніманська, підкреслюючи роль рефлексії, зазначає, що важливою умовою становлення і розвитку професійної компетентності педагога $\epsilon$ його здатність до рефлексії. «Це особливо важливо усвідомити, - підкреслює науковець, - визначаючи завдання і зміст підготовки вихователя. Коли педагог стає суб'єктом професійного самостворення, уміння оцінювати власні дії, свої особистісні властивості, себе як педагога, набуває особливої ваги» [5, с. 150].

У свою чергу, Н. Гавриш та В. Желанова вказують на те, що рефлексія є базовим психологічним механізмом педагогіки розуміння, яка сприяє усвідомленню справжніх мотивів власної педагогічної діяльності, допомагає відрізнити свої труднощі й проблеми від чужих, а рефлексивно-аналітичні вміння складають одну із провідних груп професійно-педагогічних умінь [2, с. 8].

Роль рефлексії у процесі навчання педагогів підкреслюють у своїх дослідженнях К. Крутій та Ю. Манилюк, стверджуючи, що без рефлексивної культури неможливо розв'язати проблему творчості особистості, формування мотивації дорослого до самоосвіти [3; 4].

Як один із етапів психолого-педагогічного проектування 3 дітьми рефлексивнооцінювальний етап розглядають автори технології $\Pi^{3}$, співробітники лабораторії психології дошкільника Інституту психології ім. Г. Костюка НАПН України (завідувач Т. Піроженко). За словами науковців, відбувається «подорож у часі» у зворотному порядку. У межах рефлексивної діяльності діти разом 3 педагогом навчаються усвідомлювати набутий досвід, мають змогу навчитися надавати детальну психологічну характеристику як власному особистісному розвиткові, так і оточуючих людей, оцінювати помилки й успіхи [5, с. 56].

Аналіз психолого-педагогічної літератури і досліджень із цієї проблеми виявив, що рефлексія, 3 одного боку, визнається як якість, необхідна професіоналу, оскільки дозволяє найбільш ефективно й адекватно реалізувати себе i свої здібності, забезпечуючи процес розвитку й саморозвитку, сприяючи творчому підходу до професійної діяльності, досягнення ії максимальної ефективності і результативності, 3 іншого - сутність рефлексії, завдяки якій здійснюється професійне становлення та розвиток особистості педагога, а також сукупність умов, що сприяють формуванню формованої якості, недостатньо досліджені в педагогічній психології.

Рефлексія на перших етапах свого становлення припускає цілеспрямовану іï організацію методичними службами різного рівня, що постійно і грамотно долучають педагогів до самоаналізу навчально-виховної діяльності і формування іiї компонентів, прагнуть викликати їх на міркування, формують здатність подивитися збоку на свою діяльність. Кожному педагогу внутрішньо властива здатність цілеспрямованої 
рефлексії, в інтересах представників методичних центрів і закладів післядипломної освіти допомогти йому знайти і реалізувати таку здатність. Тобто завданням викладачів і методистів є створення для педагога «рефлексивного простору», що дозволить йому абстрагуватися від своєї предметної діяльності, «зупинити мить», побачити власну навчально-виховну діяльність немовби збоку, спробувати проникнути у їі сутність і осмислити своє призначення в ній, простору, який би сприяв формуванню та розвитку рефлексивної культури.

Нами було розроблено програму заходів формування рефлексивної культури педагогів, яка, враховуючи здатності й особливості кожного педагога, уможливлює розвиток у них рефлексивних здібностей, умінь та знань. Процес формування рефлексивної культури у педагогів нами поділено на етапи: мотиваційно-цільовий, інформаційний, репродуктивно-узагальнювальний, творчий, рефлексивнооцінювальний. На кожному етапі були врахованими три рівні сформованості рефлексії: достатній, середній, низький. Робота 3 формування рефлексивної культури здійснювалася за трьома векторами: рефлексія особистого життя; рефлексія власної професійної діяльності; рефлексія як складник взаємодії з дітьми.

Задля удосконалення рефлексивних якостей педагогів ефективним на всіх етапах програми стало застосування інноваційних технологій навчання: діалогові технологіїкомунікативне середовище, простір, співробітництво на суб'єкт-суб'єктному рівні; акмеологічні технології - інтерактивні методики визначення власного професійного потенціалу; структурно-логічні технології- поетапна організація постановки дидактичних завдань, вибору способу їх розв'язання й оцінки одержаних результатів; комп'ютерні технології- за допомогою різноманітних навчальних програм (інформаційних, тренінгових, розвивальних, контролюючих), реалізованих у дидактичних системах «супервізор- комп'ютер- педагог». Використання цих технологій сприяло поглибленню рефлексивних знань та вмінь педагогів: пізнанню себе, внутрішнього світу, оцінки якості своїх станів і якостей, які сприяють самоорганізації особистості, тобто саморефлексії.

Системної реалізації у педагогів дошкільних навчальних закладів набули методи, що застосовувались на інформаційному етапі програми формування рефлексивної культури, зокрема, методи і прийоми акмеологічних технологій, концентрованого навчання і фреймового підходу. Розглянемо їх зміст більш детально.

Акмеологічні методики («акме»- вершина). Мета - визначення рівня акмеологічного потенціалу, сутність якого полягає в тому, що в «людині закладено намагання досягнути значного, гарного, корисного, доброго; шлях до вершин важкий, але незакритий ні для кого; кожна людина володіє власними неповторними задатками, прикладаючи зусилля, працюючи над собою, перетворює їх у свої достоїнства» [1, c. 231].

Наприклад, у межах дослідження нас зацікавила методика «Будівництво сходинок досягнень», метою застосування якої $є$ вправляння педагогів у навичках планування індивідуальних досягнень та рефлексії ефективності власної професійної діяльності. Сходинки індивідуальних досягнень- це таблиця, малюнок або макет «гори сходження» до бажаних результатів: в особистому житті, у стосунках з близькими, успіхах у професійній діяльності; досягнення високих рівнів фізичних та психічних якостей, рис характеру тощо.

Повертаючись до проблеми ефективного використання особистісного потенціалу кожного педагога, а також значної інтенсифікації навчально-методичної діяльності в цілому, ми використали технологію концентрованого навчання, яка надала змогу здійснювати весь процес навчання стисло, концентровано, прискореним темпом. Мета 
такої технології полягає в ліквідації калейдоскопичності відчуттів і вражень під час формування знань, роздробленості процесу пізнання і створення такого процесу навчання, при якому людина за менший, ніж раніше, час оволоділа значним обсягом грунтовних і дієвих знань.

У межах програми формування рефлексивної культури концентрований підхід дозволив:

1) структурувати матеріал для виокремлення найбільш суттєвого, необхідного задля формування системи знань за розділами «Рефлексія: історичний аспект», «Психологічні акценти у визначенні рефлексії», «Рефлексивні умови», «Рефлексивні уміння», «Критерії рефлексуючого педагога» (записи в педагогічних словничках труднощів, словничках-мінімумах, словничках-ілюстраціях, виготовлення педагогічних та методичних пам'яток, «вузликів напам'ять», «педагогічних шпаргалок», теоретичних та ілюстративних схем, таблиць;

2) вибрати оптимальні форми та прийоми навчання педагогів на основі використання укрупнених одиниць для формування рефлексивної грамотності та педагогічної культури загалом. Ідеться насамперед про методику незакінчених речень, роботу 3 асоціаціями, створення асоціативних рядів, озвучування очікуваних результатів, види рефлексивних розминок, роботу з символами, ключами, позначками, таблицями, схемами, використання коду-абревіатури, формулювання запитань, самостійне складання опорних і тезисних конспектів, пошук інформації, вправи «Знайди порушення логіки», «Знайди помилку», «Навчаючи- вчусь сам», рефлексивний диктант, використання планів-алгоритмів, взаємоперевірку, роботу 3 таблицями, символами, смисловими ключами, заповнення аркуша самоконтролю, метод ланцюжка тощо.

Прискоренню й інтенсифікації інформаційного процесу навчання педагогів значно сприяло впровадження нами фреймового підходу (ідея американського науковця M. Мінскі, 80-роки XX ст.). Сутність його полягає у згортанні й компактному поданні навчальної інформації у вигляді фрейму (англ. frame - «каркас», «схема»). Фреймовий спосіб систематизації й наочного відображення інформації базується на виявленні суттєвих та стереотипних зв'язків між елементами та створення універсальної структури, що використовується для найбільш чіткого структурування змісту навчання.

У процесі формування рефлексивної культури було використано кілька видів фреймів: понятійні (розкривають сутність ключового апарату, характеризують його головні ознаки); семантичні (розкривають значення слова); тематичні (надають змогу згорнути весь інформаційний матеріал теми у зручні для візуального сприйняття структурно-логічні схеми чи опорні конспекти); фрейми-сценарії (встановлюється чітка послідовність певних дій, ситуацій, процедур); фрейми-пояснення або фрейми-розповіді (текстові повідомлення, що містять інформацію про певну подію); інтегровані фрейми (мають складну структуру, у якій можуть поєднуватися понятійні, семантичні та інші види фреймів).

Ефективному розвиткові рефлексивної культури педагогів сприяли також численні інтерактивні ігри, медитативні вправи, кокологічні ігри тощо.

Результати дослідження довели, що 3 формуванням рефлексивної культури у педагогів пов'язано розв'язання багатьох кардинально важливих питань: підготовки педагогів до духовно-творчої самореалізації, що виявляється насамперед у відході від шаблонів і стереотипів; виробленні програми вимог до себе, процесу і результатів діяльності; усвідомлення педагогом змісту своєї професії; знаходження зацікавленого, критичного становлення до різних іiі аспектів; послідовного збагачення професійного 
досвіду і майстерності, готовності до інновацій у власній професійній діяльності засобом активної участі в інтерактивному навчанні та впровадженні технологій.

Підсумовуючи сказане, зазначимо, що рефлексію слід сприймати як форму активного особистісного переосмислення людиною того чи того змісту своєї індивідуальної свідомості. Рефлексивна культура $\epsilon$ особистісним інтегративним утворенням, структура якого охоплює сукупність знань, умінь і здібностей, які реалізуються педагогом через спеціальні дії, спрямовані на виявлення, оцінку й узагальнення найбілыш істотних ознак педагогічного процесу задля досягнення його якісних змін професійного й особистісного вдосконалення.

Формування і розвиток рефлексивної культури має стати першочерговою задачею діяльності андрагогічних служб різних рангів. Підняття на високий рівень психологопедагогічної і методичної підготовки вихователів дошкільних навчальних закладів надасть змогу педагогам поєднувати в собі професіоналізм і гнучкість мислення, винахідливість, упевненість у своїй самобутності і розвинуту інтуїцію, творчу уяву, критичну самооцінку i прагнення, здатність до постійного саморозвитку й самовдосконалення, готовність до реального впровадження новітніх технологій у практику своєї роботи.

\section{Література}

1. Акмеологія шкільної освіти: [наук.-метод. посіб.] / за заг. ред. Г. С. Сазоненко. К. : Основи, 2010. - 560 с. 2. Гавриш Н. Зрозуміти іншого, щоб наблизитися до себе / Н. Гавриш, В. Желанова // Вихователь-методист. - 2009. - №6. - С. 7-13. 3. Групові форми методичної роботи з педагогами в сучасному дошкільному закладі / за заг. ред. К. Л. Крутій. - ТОВ «ЛІПС» ЛТД, 2004. - 144 с. $\quad$ 4. Манилюк Ю. С. Шляхи удосконалення управлінської діяльності керівника дошкільного навчального закладу. Актуальні проблеми психології. T. IV : Психолого-педагогічні основи розвитку особистісного потенціалу дитини в сучасному суспільстві : зб. наук. ст. / за заг. ред. проф. С. Д. Максименка та канд. психол. наук С. О. Ладивір. - Київ, 2006. - С. 172-241. 5. Піроженко Т. О. Особистість дошкільника : перспектива розвитку : [навч.-метод. посіб.] / Т. О. Піроженко. - Тернопіль : Мандрівець, 2010. - 136 с. 6. Поніманська Т. І. Дошкільна педагогіка : [навч. посіб. для студ. вищих навч. закладів]/ Т. І. Поніманська. - К. : Академвидав, 2004. - 456 с.

\section{СУТНІСНІ ОЗНАКИ ІННОВАЦІЙНОГО СЕРЕДОВИЩА ЗАГАЛЬНООСВІТНЬОГО НАВЧАЛЬНОГО ЗАКЛАДУ}

Коновальчук I. I. Сутнісні ознаки інноваційного середовища загальноосвітнього навчального закладу.

У статті розглянуто сутнісні ознаки, структуру, функції і критерії інноваційного середовища загальноосвітнього навчального закладу. Із позицій системного підходу інноваційне середовище визначено як цілісність соціально-психологічних, організаційно-педагогічних, інформаційно-комунікативних, матеріальних, технологічних та інших умов, що в єдності постають засобом стимулювання, підтримки, управління, рефлексії інноваційної діяльності педагогів та їх професійного розвитку. За змістом інноваційне середовище - це сукупність інновацій, що створюють нові можливості для розвитку навчального закладу.

Ключові слова: нововведення, середовище, середовищний підхід, інноваційне середовище навчального закладу, інноваційна діяльність. 